\title{
Greening the Belt While Paving the Road? China's Environmental Diplomacy Challenge
}

\author{
American Political Science Association \\ Annual Meeting (Virtual) \\ San Francisco CA USA (originally scheduled) \\ Panel: China and the World: Challenges and Opportunities \\ Global Forum of Chinese Political Scientists
}

September 12, 2020

Steven F Jackson, PhD

Indiana University of Pennsylvania

Department of Political Science

Indiana, PA 15705

sjackson@iup.edu 


\begin{abstract}
The rise of China and the pollution in China have been two intertwined images of the $21^{\text {st }}$ century. One of the challenges that China's foreign policy faces in the $21^{\text {st }}$ century revolves around its leadership in global and regional environmental initiatives. The policy shift on climate change at the 2016 Paris Climate Summit and the personal negotiations of Presidents Xi Jinping and Barack Obama showed a willingness to work cooperatively with the United States on achieving global goals toward limiting climate change. For China, the abrupt announcement of the Trump Administration that it is leaving the Paris Accord is an opportunity to assume a leadership role in climate policy.

Seizing this opportunity, however, must also deal with China's major program - the Belt and Road Initiative (BRI). There is little doubt but that China is now seeking to portray its efforts as environmentally friendly. The foreign policy question is how well this effort has worked. This study will seek to evaluate external perceptions, both official and media, of major developing countries such as Pakistan, Bangladesh, and Kenya which have expressed support for the BRI and contrast them with other countries such as India which have resisted it. The focus will be the way in which the environmental impact of the BRI is characterized by these countries. In the case of the China-Pakistan Economic Corridor, the power plants built were half coal-fired and half renewables, something the Pakistani government proudly touted. Are other participants seeing it this way as well?
\end{abstract}




\section{Introduction}

China's pollution problems are famous: beginning in the early 2000s, Beijing's urban air pollution was the photographed and tested as the worst in the world. Its lakes and rivers were even worse. Off shore, this river pollution and runoff caused much of its coasts are subject to eutrophication, and parts of Hangzhou Bay and the Bohai Gulf are effectively dead. In 2008 when it hosted the Olympic games, the contrast between China's gleaming $21^{\text {st }}$ century buildings and efficient transportation infrastructure and the pollution made the link between all of the construction and environmental damage clear to much of the world. In 2009, China had the dubious distinction of becoming the world's largest single carbon-emitting country, displacing the United States. Thus, when a new Chinese President, Xi Jinping, announced four years later that China would embark on a new infrastructure-building initiative called the Silk Road Economic Belt (丝绸之路经济带/sīchóu zhì lù jīngjì dài) and the $21^{\text {st }}$ Century Maritime Silk Road (21 世纪海上丝绸之路/21 shìji hăishàng sīchóu zhì lù), collectively called the One Belt, One Road (一带一路/yżdài yìlù), and directed not within China but to connect China to other places along the route of the ancient Silk Road, many external critics worried that China was not merely exporting its connectivity to Eurasia but its bad pollution habits as well.

By April 2019, China was hosting its second major international forum about the renamed Belt and Road Initiative (BRI) ${ }^{1}$ and the theme was a Green Belt and Road. Much of the 2019 meetings focused on the environment and carbon-neutral methods of developing the infrastructure of an expanding realm of the BRI. The BRI International Green Development Coalition and Green Investment Principles for the Belt and Road Development were part of Beijing's apparent commitment to "Greening" its most prominent overseas initiative.

\footnotetext{
${ }^{1}$ Although the official English translation of 一带一路 was changed in late 2015 to “Belt and Road Initiative," the name in Chinese is unchanged.
} 
What happened?

This paper seeks to examine when China began to emphasize the "Green" aspect of its Belt and Road initiatives, and why it chose to do so. To be clear, although it will deal with the charges of "Greenwashing" that are sometimes leveled at the initiative, it is beyond the scope of this research to reach an objective, scientific conclusion as to whether China's BRI projects and undertakings are truly "Green" or not. This is a paper about foreign policy, not environmental science.

\section{Background of BRI}

"Much of East Asia continues to grow rapidly.... Urbanization is proceeding at a rapid pace. Demand for infrastructure services is increasing massively, particularly in cities. Much of the demand comes from the newly urbanized poor. Infrastructure has to meet the needs of this population, but also has to continue to provide the underpinnings for the region's growth" (ADB 2005, xxi). So began Connecting East Asia: A New Framework for Infrastructure, a 300-page report on the infrastructure challenge of the region authored by the Asian Development Bank, the Japan Bank for International Cooperation and the World Bank. The report focused on the need for paved roads, electricity, clean water, railroads, ports, airports, and in particular around urban areas which were seeing the most rapid population growth (ADB 2005, 1-16). The costs were estimated to be enormous: “...to meet expected infrastructure service needs, East Asia would have to spend $\$ 165$ billion a year over the next five years - or roughly 6.2 percent of its GDP annually — on electricity, telecommunications, water and sanitation, and major transport networks" (ADB 2005, 29). The report also noted that poorly-designed infrastructure could have significant environmental risks, and highlighted the need for social inclusiveness in design and implementation. Another ADB report in 2009 continued the theme, Infrastructure for a Seamless Asia, and that report was followed in 2012 by Infrastructure for Asian Connectivity, 
edited by Biswa Nath Bhattacharyay, Masahiro Kawai, and Rajat M. Nag of the ADB. In short, the Asian infrastructure imperative was quite clear.

But who could build it? In 2005, the United States was mired in two on-going wars in Afghanistan and Iraq, and in 2008 the global financial crisis that started on Wall Street and then led to the European Debt Crisis, so much of the West was out of the question. China, however, had survived the global financial crisis in good condition, just as it had survived the 1997 Asian Financial Crisis, and was looking to take a more prominent leadership role in the world.

The United States government, however, was reluctant to cede influence to Beijing. The voting shares in the World Bank and International Monetary Fund were skewed heavily toward the Western industrial democracies in general and the USA in particular, and despite diplomatic efforts made with the Voice Reform phase 2 (WB 2010), the US government would not grant more influence to China. Furthermore, many Western banks and institutions were narrowing the list acceptable forms of infrastructure. In 2000, there was a move away from large hydroelectric dams as power-generators, given environmental and social issues of displaced peoples (World Commission on Dams 2000). At the same time that there was an enormous need for infrastructure in Asia, and in particular electrical generation, major Western banks and insurers were increasingly following the World Bank’s 2013 lead and declining to fund coal-fired electrical power plants (Buckley 2019).

\section{OBOR - the Beginning}

The One Belt One Road idea was first articulated by Xi Jinping on September 7, 2013 at a speech at Nazarbayev University in Astana (now Nur-Sultan), Kazakhstan, which was initially described as an "economic belt along the Silk Road," and specifically invoking the legacy and geography of the ancient Central Asian Silk Road (Xi Jinping 2013a). This was followed by a 
speech to the Indonesian parliament a month later, in which Xi called for "Maritime Silk Road of the 21st century" (Xi Jinping 2013b). Although neither speech had any mention of environmental goals, Xi did answer questions from Kazakh students about environmental issues surrounding the idea. The response is worth quoting at length:

China clearly puts the protection of the ecological environment in a more prominent position. We need not only economic growth but also good ecological environment, and we prefer good ecological environment rather than economic growth. In fact, good ecological environment itself is a valuable wealth. We must not pursue economic development at the expense of ecological environment. We have put forward a strategic task of the construction of ecological civilization and the building of a more beautiful China with blue sky, green space, and clean water for future generations (Xi Jinping 2013c).

It is interesting that the first association of environmental issues and the BRI per se came not in the original speech that $\mathrm{Xi}$ gave, but in response to a foreign query. Xi's October speech to the parliament of Indonesia also made no mention of environmental issues or goals, but his speech to the APEC CEO Summit the same month did make mention of a "master plan ....to press ahead with reforms in economic, political, cultural, social and ecological fields” (Xi Jinping 2013d). He also mentioned improving the environment in China, and contributing to the global response to climate change, but no direct connection to the OBOR idea.

Fig. 1 - Xinhua Map of the One Belt One Road

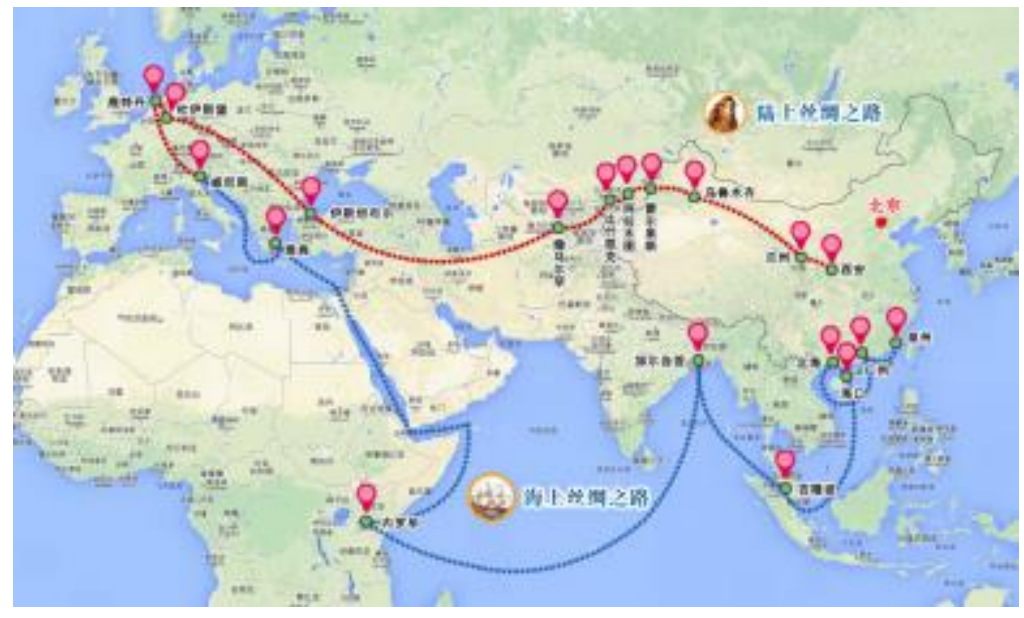

Source: Xinhua 2014 cited in Tiezzi 2014. 
It would appear that the first two senior officials to explicitly link the OBOR and environmental protection were Premier Li Keqiang and State Counselor Yang Jiechi in their April 2014 speeches at the Boao Forum. Li was discussing the belt and road ideas, the AIIB, and passingly mentioned the “...'new economy’ featuring green development, energy environmental protection and the internet so as to seize an advantageous positions in future development..." (Li Keqiang 2014). Yang's speech also mentioned ecological protection in a long list of areas of cooperation with countries along the belt and road: "We will advance our cooperation with them in trade, industry, investment, energy and resources, finance and ecological protection, and strengthen cooperation on urban development, ports, land ports and industrial parks. Efforts will be made to nurture new growth points, support local employment, improve local capacity for sustainable development and realize common development of China and these countries" (Yang Jiechi 2014).

Within the Chinese bureaucracy during the first two years after its announcement, the BRI initiative was given modest mention in Chinese official documents of the Ministry of Foreign Affairs in its official yearbook, China's Foreign Affairs (hereafter “CFA”)/ 中国外交 (Zhōngguó wàijiāo). The website of the Ministry of Foreign Affairs lists a few speech titles that mention "Silk Road" in 2015 but no speeches using the term "Economic Belt" that year, and neither term appears in a speech title in 2014. Xi's OBOR was not the only slogan being slung in 2013-15; “Chinese Dream” (中国梦/Zhōngguó mèng) was Xi’s earlier slogan beginning in 2012, meant to displace his predecessor Hu Jintao's “Harmonious Society” (和谐社会/ héxié shèhui).

Not surprisingly, the Ministry of Environmental Protection in February 2015 wedded the idea of the economic belt along the Silk Road with the older term, "ecological civilization" (生态 
文明/Shēngtài wénmíng) when Vice Minister Li Ganjie met his Kazakhstani counterpart during the China-Kazakhstan Environmental Cooperation Committee (MEE 2015a). Li repeated the connection in his meeting with his Cambodian equivalent in July as well, and called for a "green belt and road,” (绿色 “一带一路” / lù̀sè “yìdài yìlù) perhaps the first use of that phrase (MEE 2015b), and in September called it a "green silk road" (MEE 2015c). This despite the fact that it was the NDRC, the MOFA and the Ministry of Commerce were the responsible bureaucracies for the BRI "Vision and Action" document and not the Ministry of Environmental Protection (now the Ministry of Ecology and the Environment). ${ }^{2}$

At the same time, former Foreign Minister Li Zhaoxing speaking at a Maritime Silk Road of the $21^{\text {st }}$ Century symposium also mentioned environmental protection in a long list of items to be promoted: “...we must seize the opportunities of rapidly growing global ocean economy, and establish pivots and corridors for maritime economic cooperation. ...we will intensify efforts to promote maritime transportation, resource development, environment protection, scientific research, tourism, archeology, and port economic zone development” (Li Zhaoxing 2015). All of these speeches follow a pattern of a passing reference to environmental protection in a long list of other goals, but none put them in a prominent position or gave details.

That changed with the March 2015 with the release of the National Development and Reform Commission's "Vision and Actions on Jointly Building Silk Road Economic Belt and $21^{\text {st }}$ Century Maritime Silk Road" (NDRC 2015). The first edition of the document was issued by the NDRC, the Ministry of Foreign Affairs (MOFA) and the Ministry of Commerce. In the discussion of cooperation priorities, the NDRC made several points about environmental issues and the BRI: "At the same time, efforts should be made to promote green and low-carbon

\footnotetext{
${ }^{2}$ The works cited page uses the current name of the bureaucracy for all references.
} 
infrastructure construction and operation management, taking into full account the impact of climate change on the construction." At the same time, it was clear that energy, including oil and gas pipelines were part of the focus as well, but the report also stated "We should increase cooperation in the exploration and development of coal, oil, gas, metal minerals and other conventional energy sources; advance cooperation in hydropower, nuclear power, wind power, solar power and other clean, renewable energy sources..." It continued the theme in trade and investment: "We should promote ecological progress in conducting investment and trade, increase cooperation in conserving eco-environment, protecting biodiversity, and tackling climate change, and join hands to make the Silk Road an environment-friendly one." All told, there are about 110 words (in the English language version) discussing environmental aspects of the BRI out of a total of 5,671, or about $1.9 \%$ of text content. Xi Jinping's address to the Boao Forum that same month, however, made only one passing reference to "environmental protection" and one to "climate change" (Xi Jinping 2015). Yang Jiechi's speech at Boao mentioned environmental protection twice in 2015 . The speech also made a cryptic reference to standards that may have been a slight of environmental protection: "Countries along the Belt and Road differ in national conditions and vary greatly in level of maritime development and protection. It is neither realistic nor advisable to measure them against the same set of ideas, plans and model of cooperation [emphasis added]. One of the original features of the 21st Century Maritime Silk Road is its much stressed connectivity. It is not about one party accepting the plan made by another or one party following the rules set by another." Xi Jinping's brief remarks about the founding of the AIIB did not mention environmental goals for that institution in January 2016, Vice Foreign Minister Qian Hongshan mentioned it once at the ESCAP Belt and Road Side Event speech in May 2016 (Qian Hongshan 2016). Thus, it would appear that the emphasis on 
"Green," environmental protection and associated concepts among the top leadership of China was minimal from 2013 to 2016. To be sure, the 2015 NDRC "Vision and Action" document had a few passages focusing on environmental protection, but the top leaders when speaking of the BRI mentioned them only passingly as one item in a long list of goals and values. The officials of the Ministry of Environmental Protection (renamed Ministry of Ecology and Environment in 2018) were an exception, and they did use the term "Green Belt and Road" (绿 色“一带一路” / lù̀sè “ỹ̄dài yūlù).

That trend appears to have changed significantly in the summer of 2016. Two events seem to have indicated a sudden increase in top-leadership attention to the issue. First, Xi Jinping gave a speech to the Uzbekistani parliament, and second there was a major conference with international NGOs in Guiyang. Xi's speech specifically called for a "green, healthy, intelligent and peaceful" Silk Road and "Xi suggested that the partner countries deepen cooperation in environmental protection, intensify ecological preservation and build a green Silk Road" (Xinhua 2016a). The July 2016 meeting of the Eco Forum Global Annual Conference in Guiyang thus occurred at an opportune time; the Chinese NGO has existed since 2009, and this meeting was well-reported in the Chinese media, and noted the involvement of the Chinese branch of World Resources Institute (WRI) (Xinhua 2016b).

If 2016 saw the first use of "Green" by a top leader's speech in China, 2017 saw the term go from passing mention to a regular discussion. Scholarly articles using the title "Green Belt and Road” ( “绿色一带一路” ) in CNKI (China National Knowledge Infrastructure, an academic periodical database) grew from 3 in 2015 to 5 in 2016 and then 61 in 2017. This was closely linked to the May 2017 Belt and Road Forum in Beijing, a carefully-orchestrated extravaganza designed to announce the BRI to the world and glorify its chief proponent, Xi 
Jinping, and it was even included in the Chinese Communist Party's official ideology in 2017.

Shortly before the Forum began, the Office of the Leading Group for the Belt and Road Initiative released a long document (60 pages in English), published by Foreign Languages Press Building the Belt and Road: Concept, Practice and China's Contribution (hereafter "Concept, Practice"). For two years this was the guiding document for the BRI, and devoted even more text space$7.8 \%$ of total -- to environmental issues than the 2015 NDRC "Vision and Actions" document $(1.9 \%) .^{3}$ Xi's own welcoming speech had a paragraph on "green development" and about $3 \%$ of its text discussed environmental priorities of the BRI, most notably "We should pursue the new vision of green development and a way of life and work that is green, low-carbon, circular and sustainable. Efforts should be made to strengthen cooperation in ecological and environmental protection and build a sound ecosystem so as to realize the goals set by the 2030 Agenda for Sustainable Development” (Xi Jinping 2017).

In addition, Chinese authorities released a twelve-page document The Belt and Road Ecological and Environmental Cooperation Plan in May and the State Council and Central Committee issued "Guidance on Promoting Green Belt and Road” in May 2017 (State Council 2017). This document makes clear that at least on paper, there was serious commitment to environmental issues in the construction of the BRI: "Green concept as the priority and cooperation-based sharing. We will prioritize the concept of ecological civilization and green development, focus on the incorporation of eco-environment protection and socio-economic development, actively integrate the relevant strategies and plans with countries or regions along

\footnotetext{
${ }^{3}$ Note: This counts all words of a paragraph or section that is completely devoted to environmental issues. The "Concept, Practice" document had Chapter II section 5 entirely devoted to environmental issues. Other mentions of environmental issues count the entire sentence's words or the clause in which the phrase occurred. Key words and phrases searched were: "environmental” (15), "green" (11), "ecology" (7), "sustainable" (8), "carbon” (2), "pollut" (1), "wildlife" (3), "natural" (0), "renewable" (1), "climate" (8). Each key word hit was checked for relevance. For example, two uses of "sustainable" were not environmentally-related and not counted.
} 
the route, strengthen policy dialogues on eco-environment protection, enrich cooperation mechanisms and exchange platforms, and promote the sharing of green development results" (State Council 2017). The document also points to international trends as a source of policy shift: "Promoting green Belt and Road responds to the international trend of seeking green, lowcarbon and circular development" (emphasis added).

At the same time, the State Council "Guidance" does direct a time span that might not be as impressive: “. . lay a solid foundation for green 'Belt and Road' Initiative within 3 to 5 years; we also aim to build a relatively complete eco-environment protection service, support and guarantee systems, implement a cohort of key eco-environment protection projects and achieve favorable results within 5 to 10 years." The document does direct Chinese businesses to “observer international regulations on economy and trade and the laws, regulations, policies and standards of the host countries on eco-environment protection [and] attach great importance to the appeals of the local residents on environment protection..." However, as noted by many NGOs, the standards of some of the countries along the belt and road might not be the highest in the world, and Chinese companies' observation of them might not be the most faithful in the world.

The next month, the NDRC and the State Oceanic Administration issued their own vision document specifically on maritime cooperation and the concept of a “blue economy.”(蓝色经济 /lán sè jīngjì) ${ }^{4}$ This was its own vision for the21st Century Maritime Silk Road, and included substantial attention to "Green development" as well (MEE 2017).

\footnotetext{
${ }^{4}$ This refers to marine development, a policy that China began in the 1990s, according to Julia Guifang Xue (2005), 75.
} 
The incessant use of "One Belt One Road" and BRI in Chinese media in 2017 is remarkable. The CNKI.net (a Chinese academic periodical database) also shows the slow start of “一带一路” in article titles, and then a rapid growth, as shown in Table 1:

Table 1 -- CNKI Periodical Articles with “One Belt One Road”, 2013-2020

\begin{tabular}{lr|r}
\hline Year & Subject Hits & \multicolumn{1}{r}{ Title Hits } \\
\hline 2013 & 3 & 0 \\
2014 & 1,956 & 748 \\
2015 & 23,120 & 10,121 \\
2016 & 22,229 & 8,776 \\
2017 & 38,518 & 17,632 \\
2018 & 34,587 & 13,888 \\
2019 & 24,323 & 13,660 \\
2020 (partial as of & 4,891 & 2,838 \\
24 June 2020) & & \\
\hline
\end{tabular}

Source: CNKI, author's search input June 24, 2020. "Subject Hits" refer to articles with a subject heading of “一带一路”; “Title Hits” refer to articles with “一带一路” in its title.

By the time the Second Belt and Road Forum was convened in 2019 (also in Beijing), Xi's opening address was much shorter than his speech in 2017 (612 words in English translation versus 4091), about ten percent of it was focused on environmental issues (Xi Jinping 2019).

\section{Western Reaction}

In western media, reporting on the OBOR/BRI lagged behind that of China in the first years. The first mention of "One Belt, One Road" in the New York Times came in March 12, 2015 in an article about steel overcapacity in the Chinese economy and the effort to use OBOR to export steel (Gough 2015). Two more articles mentioned the initiative that year in the Times. The Washington Post also had three articles that mentioned OBOR in 2015. In 2016, the Times had an Op-Ed by former Clinton Administration official Clyde Prestowitz that mentioned the One Belt, One Road (Prestowitz 2016), and a half-dozen that discussed the Belt and Road Initiative or the "New Silk Road" by name. None of the 2016 Times articles mentioned 
environmental concerns about the BRI. In 2017, the Times first put "Belt and Road" in a headline (May 14) and five articles focused exclusively on the initiative. This was also the time of the first Belt and Road Forum in Beijing, when the whole world began to recognize, discuss, criticize and praise the BRI. But there was as yet no mention of environmental consequences. Much of the Western discussion, in 2014-15, however, was focused on the Asian Infrastructure Investment Bank (AIIB), which was characterized as a "Rival to the World Bank," and which the Obama Administration decided to oppose, only to see significant US allies such as the UK and Australia join anyway. Xi Jinping's October 2013 Indonesia speeches (the first to its parliament and the next at the APEC summit) specifically mentioned the creation of a bank for funding the infrastructure goals of the OBOR, and it was this bank that initially caught western media and government attention, not the broader initiative. Secretary of State John Kerry (standing in for President Obama because of the government shutdown in Washington) initially seemed to welcome the idea, but once back in Washington, the enthusiasm turned to indifference then to skepticism and finally opposition. The objections were that "This lack of openness about operations and intentions has U.S. officials concerned that China will create an AIIB that fails to meet widely accepted international norms on issues including environment, labor, and anticorruption" (Ratner 2014). These objections were repeated frequently as the bank gained momentum, and despite a concerted effort to point to these potential problems by Washington, major US allies including the UK, France, Germany, Italy, Australia and South Korea all joined in the spring of 2015, each time reinforcing the narrative of US diplomatic disaster (see Perlez 2014; Wright 2015; Sobolewski and Lange 2015).

One of the major difficulties the US had in opposing what it regarded as a challenge to the idea of environmental, transparency, and social considerations in multilateral lending was 
that it had blocked China from taking on a larger role at the IMF and World Bank, yet was not willing to increase its contributions to the need for infrastructure around the world. As Jane Perlez aptly summarized, "One problem is that Washington did not offer much of an alternative to China's call to inject far more funding into building roads, railroads and pipelines around Asia, much of which remains underdeveloped" (Perlez 2015a). Desai and Vreeland of the Washington Post were even more blunt about the appearance of the US policy: "In effect, the United States is informing fast-growing Asian nations: We are not going to increase official funding for your important needs anytime soon; we are also going to prevent the institutions we control from increasing their funding for those needs; and lastly, we are going to admonish others from devising other ways of funding you. No wonder that Asian governments have jumped on the AIIB bandwagon" (Desai and Vreeland 2015). But it is particularly noteworthy that the western media treatment of the AIIB seldom made more than a passing reference to the "new Silk Road," or the "One Belt One Road" idea.

Chinese leaders did, however, seek to address some of the criticism in the design of the bank. Jin Liqun, a highly-respected Chinese official who had worked at the World Bank and speaks fluent English, was appointed its head, and much of its professional staff in Beijing are international. Jin quipped that he wanted the AIIB to be a "lean, clean and green bank" (Perlez 2015b). The bank's website of approved projects includes information on the environmental standards surrounding projects, many - but not all - which use World Bank Environmental and Social Safeguard Policies (Safeguard Policies) (AIIB 2020). As of July 2020, the bank has lent \$20 billion (Xi Jinping 2020).

There are other Chinese state-owned entities which are involved in BRI projects, such as the Silk Road Fund (丝路基金/ sī lì jījīn), which was announced and established in late 2014. 
Unlike the AIIB, it is solely owned and capitalized by Chinese state entities many of which are associated with the People's Bank of China, its central bank. And unlike the AIIB, it takes equity shares in BRI projects, and has invested \$6 billion in fifteen projects as of 2017 in Russia, Central Asia and elsewhere (Silk Road Fund 2020). Several of the investments are in energyrelated areas, such as a 10\% stake in the Russian SIBUR Holdings, and a 49\% stake in a Saudi renewable energy platform (Silk Road Fund 2019). Its website, however, does not show the level of detail about its projects that is found in the AIIB website.

\section{Sources of Policy Changes}

The treatment of environmental issues associated with the BRI shifted and shifted fairly abruptly during the first four years of the initiative. In 2013-14, environmental issues were at most a passing reference in Chinese statements about the BRI, but suddenly became a major focus in 2016-17, and again a major focus in 2019; why the sudden shift?

One analytical approach to this question comes from a German scholar, Berthold Kuhn (Kuhn 2018). This approach divides policy changes into "push" and "pull" factors: "Push factors primarily refer to crisis situations, pull factors to emerging opportunities for policy changes. The distinction appears to be relatively simple but effective. It demonstrates that policy shifts are usually driven by motivations to overcome crisis situations as well as taking on opportunities" (Kuhn 2018,364). My analysis will extend on this dichotomy by dividing it further into internal and external push/pull factors. Table 2 summarizes the factors leading to the policy change/rhetorical shift: 
Table 2 -- Factors Leading to Policy Change

\begin{tabular}{|c|c|c|}
\hline & Internal Factors & External Factors \\
\hline$\overbrace{0}^{\frac{\pi}{n}}$ & $\begin{array}{l}\text {-Domestic Pollution } \\
\text {-Domestic NGOs } \\
\text {-Environmental Bureaucracy }\end{array}$ & $\begin{array}{l}\text {-“Green” Global Trend } \\
\text {-Foreign Govt Criticism } \\
\text {-Foreign Media Criticism } \\
\text {-Foreign NGO Criticism }\end{array}$ \\
\hline 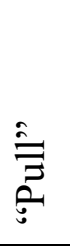 & $\begin{array}{l}\text {-"New Technology" } \\
\text { Opportunities }\end{array}$ & $\begin{array}{l}\text {-“Green" Leadership Image } \\
\text { for China in Eurasia } \\
\text {-Absence of US Leadership } \\
\text {-Inadequacy of WB/ADB } \\
\text { Lending }\end{array}$ \\
\hline
\end{tabular}

Source: Author, based on Kuhn 2018.

External Push Factors. The BRI initially was a Chinese response to a general push from major nations that China should shoulder more responsibility for the peace and development of the world, and it said so explicitly: "China is committed to shouldering more responsibilities and obligations within its capabilities, and making greater contributions to the peace and development of mankind" (NDRC 2015). The further recognition that the world had started down a trend toward "greening" development can be seen in a number of events in 2015-16 that helped push China's policy toward a Green Belt and Road. The State Council's Guidance document acknowledges that "Promoting green Belt and Road responds to the international trend of seeking green, low-carbon and circular development” (State Council 2017, emphasis added). Among the broad global trends pushing China were the adoption of the UN Sustainable Development Goals in 2015 and the Paris Climate Accord in late 2015.

The degree to which external criticism by both governments and non-governmental organizations (NGOs) influenced China's policy shift is difficult to assess with certainty, but the formation of the Asian Infrastructure Investment Bank seemed quite clearly to be a response to US Government criticisms, and European concerns about previous Chinese development projects. 
US Government comments on the BRI were first noted during the Obama Administration in March 2015 but were largely directed at the AIIB. Deputy Secretary of State Antony J. Blinken speaking at the Brookings Institution questioned aspects of the AIIB: "What are the governance rules of the bank? What role does the board of directors play? What are the standards that it would advance in terms of worker rights, environmental protections, intellectual property, capital requirements, things of that nature? .... What we don't want to see happen is some kind of race to the bottom where the standards are diluted, and that's been our only concern (Blinken 2015, emphasis added). At that time, the United States had its own program for infrastructure and connectivity in Asia called "The New Silk Road" and State Department officials pushed it in 2016 (though without much success); evaluations of the BRI tended to be skeptical, such as Assistant Secretary of State Daniel Russel's statement that “'One Belt, One Road is an attempt to name a very poorly defined or undefined set of policies and programs. And in all honesty, I 've found that my Chinese counterparts themselves have difficulty explaining exactly what One Belt, One Road is and isn't” (Russel 2016). Kurt Tong, Principal Deputy Assistant Secretary speaking a month later politely remarked that "We hope China's economic assistance will align with the needs of recipient countries, global standards and time-tested safeguards for infrastructure investment" (Tong 2016). One former Obama Administration official said of the period, "When I think back, we didn't really talk about the belt and road... There was an initial period where people were trying to figure out what was this thing" (Gan and Delaney 2019).

The Trump Administration was initially somewhat circumspect about the BRI. The National Security Council staff member responsible for China, Matthew Pottinger, attended the May 2017 forum as an "observer"; compared to the long list of heads of state and government who showed up that was a low-level presence, but a presence nonetheless (Gan and Delaney 
2019). By the autumn of 2017, however, officials such as Defense Secretary James Mattis and Secretary of State Rex Tillerson were criticizing the BRI. However, most of these criticisms were focused on the "Debt Trap Diplomacy" criticism of the BRI, pointing to the problems at the Sri Lankan port of Hambantota which the government in Colombo was forced to lease to Chinese interests in December 2017 when it was unable to pay for the infrastructure.

The Trump Administration's only criticism of the environmental issues surrounding the BRI came from a particularly shrill speech by National Security Council Advisor John Bolton at the Heritage Foundation on December 13, 2018: "China uses bribes, opaque agreements, and the strategic use of debt to hold states in Africa captive to Beijing's wishes and demands. Its investment ventures are riddled with corruption, and do not meet the same environmental or ethical standards as U.S. development programs" (Bolton 2018, emphasis added). The official 2020 White House United States Strategic Approach to the People's Republic of China was fairly similar: "The United States welcomes contributions by China to sustainable, high-quality development that accords with international best practices, but OBOR projects frequently operate well outside of these standards and are characterized by poor quality, corruption, environmental degradation, a lack of public oversight or community involvement, opaque loans, and contracts generating or exacerbating governance and fiscal problems in host nations" (National Security Council 2020, 4). All of these criticisms, however, seem to have largely come after the enormous "green" push found in 2016-17. Thus, it does not appear likely that China's policy/rhetorical change came as a result of US criticism, which was muted and passing until the Fall of 2017.

What of criticisms from international non-governmental organizations? There have been scores of reports on the BRI from think-tanks and environmental groups. European scholars 
were among the first to discuss the BRI, given previous Chinese investments such as the Port of Piraeus in Greece (van der Putten and Meijnders 2015). In September 2015 the European Commission and the NDRC signed a Letter of Intent linking the BRI with the EU's TransEuropean Network Transportation (TEN-T) policy. The latter was seen as an important part of the EU's efforts to reduce carbon emissions and dependence on petroleum, so the linkage was seen as having potential benefit for the environment (Schüller and Schüler-Zhou 2015). Australia’s Lowy Institute published a report by Peter Cai in March 2017 that focused substantially on the excess domestic production capacity reasons for the BRI: "The Chinese Government also wants to use OBOR as a platform to address the country's chronic excess capacity. It is more about migrating surplus factories than dumping excess products" (Cai 2017, 1). The report does not, however, deal with the environmental implications of the transfer of excess capacity to Belt and Road countries. (That came in November 2017 in a Lowy Institute report by Sam Geall, see below).

US Think tanks. RAND was among the first US think tanks to mention "the new Silk Road" but one of the first substantial US-based reports to focus on it was Christopher K. Johnson for CSIS in March 2016. Concerns about the environment are passingly noted: "China faces several challenges in implementing OBOR that it is unlikely to be able to anticipate or control. These include environmental concerns, both domestically and abroad, as well as substantial uncertainties in the target countries and regions, such as political instability, economic difficulties, ethnic and religious complexities, and poor infrastructure" (Johnson 2016, 21, emphasis added). Johnson noted that previous Chinese overseas resource development projects had often had negative consequences: “...under Jiang Zemin in 2002 [China] encouraged SOEs [state-owned enterprises] to invest abroad, primarily in extractive industries.... The resulting 
environmental degradation, poor treatment of local populations, and tendency of firms to import Chinese labor helped create a negative image for China abroad" (Johnson 2016, 6).

As with the US government, US think tanks tended to focus on the AIIB rather than the broader BRI; a short piece from The Bretton Woods Project was quite skeptical of the potential environmental problems of the AIIB: "There were concerns raised by civil society ...[on] the reliance on corporate and country systems; lack of detail on the AIIB's oversight mechanism; the omission of coal from its exclusion list; its adopted of the phrased approach, which allows plans for impact on indigenous groups to be made after project approval, and the lack of requirement of mandatory environmental or social impact assessments for projects in Category B, defined as having limited environmental and social impacts" (Kamal and Gallagher 2016, 4). A longer piece out of the Congressional Research Service in March 2017 also focused on the AIIB, with fairly favorable preliminary assessment of environmental standards there (CRS 2017, 13).

The May 2017 Belt and Road Forum in Beijing caught the attention of US think tanks, and a flurry of reports came out in May and June 2017. One of the first efforts to determine whether the BRI was achieving any sort of success came from the American Enterprise Institute's Cecilia Joy-Perez and Derek Scissors in May 2017 just after the Belt and Road Forum. The AEI's China Investment Tracker has been tracking investment deals and announcements. The report is skeptical about whether the BRI will yield long-term influence for China in partner countries, and there is no discussion of environment issues (Joy-Perez and Scissors 2017). Increasingly, by 2018, US think tanks assessments of the BRI tended to be at best skeptical and often critical. Environmental issues were often mentioned, though the primary criticisms concerned the strategic initiative the BRI gave China to increase its influence, the potential for "debt trap diplomacy" and questions about feasibility in general. 
International NGOs. Major international environmental NGOs also followed the Belt and Road Forum. Greenpeace, one of the largest and most influential NGOs, urged sustainability as a priority during the Forum: "'Shaping the Belt and Road initiative with the environment in mind is key to setting the new "China story” right,' said Greenpeace campaigner Yixiu Wu. 'The initiative should be used to promote renewable energy and environmental sustainability on a global scale.' Greenpeace urges that environmental impact assessments be integrated into the Belt and Road initiative and that the results of these assessments be made publicly available." The press release also positively noted the "Green Belt and Road" mentions in the "Guidance" document (Greenpeace 2017b). Greenpeace also noted the Trump Administration's decision to withdraw from the Paris Climate Accord and Xi Jinping's urging the USA to stay in (Greenpeace 2017a).

The World Resources Institute, another prominent NGO, had already been involved in a Chinese NGO the Eco Forum Global Annual Conference in the July 2016, and its blog report in May 2017 urged leaders to make sure that the initiative was sustainable in a number of different ways such as promoting sustainable development by using China's own [recent] success: "Through the BRI, China can promote and demonstrate green growth on a larger scale by supplying cheap renewable energy equipment to other countries..." as well as applying China's 2016 Guidelines for Establishing the Green Financial System (Zhu 2017). Other NGOs' reports came in the next few months, such as the Friends of the Earth's Investing in a Green Belt and Road? in November 2017. The 97-page report follows on a 2014 report on China's Green Credit Guidelines for its banks' overseas lending and is largely based upon case studies in a number of countries (the APRIL Pulp and Paper Mills, Indonesia; Hambantota Port, Sri Lanka; JakartaBandung High Speed Rail Project, Indonesia; Lamu Coal Power Plant, Kenya; Mes Aynak 
Copper Mine, Afghanistan; Sasan Ultra Mega Coal Plant, India; Yamal LNG Project, Russia) along the belt and road, but not necessarily part of the BRI (such as India). The results were generally quite negative: "Five years after the publication of the Green Credit Guidelines, Chinese banks are falling short in fulfilling the GCG's mandate to comply with host country law and international standards in overseas lending. In particular, banks continue to struggle in localizing their environmental and social risk assessments to host countries' legal system, and still have a long way to go in building institutional capacity, understanding, and applying international norms and standards" (Friends of Earth 2017, 59).

The World Resources Institute, after giving cautious praise to the BRI immediately after the Belt and Road Forum, issued a Working Paper in October 2018 that was much less generous (Zhou et al. 2018). Examining energy and transportation loans from major Chinese banks and equity investments including from the Silk Road Fund in relation to the Nationally-Determined Contributions (NDCs) of the Paris Climate Accord, the Working Paper found growing Chinese investment and loans in BRI countries (2), but "According to the data received, most Chinese deals in energy and transportation are still tied to traditional sectors and do not show a strong alignment with the low-carbon priorities included in BRI governments' NDCs" (3). The electric power segment of the BRI loans was notably carbon-intensive: “...over half (54 percent, or \$14 billion) of the syndicated loans were used to finance fossil-fuel power plants, including $\$ 10$ billion for coal-fired power plants...About a third of the syndicated loans were used to finance renewable energy; two-thirds of that amount was for hydropower in Pakistan...Apart from hydropower, the six Chinese banks supported syndicated loans of geothermal power in Indonesia, solar PV in Egypt and the Republic of Korea, and wind power in Pakistan and India” (13). 
Greenpeace International examined the energy sector as well, though its analysis noted the rapid rise in renewable energy investments between 2014 and 2019: "Since 2014, Chinese equity investment has supported a total 12,622 megawatts of wind and solar PV projects combined along the Belt and Road. Before 2014, only 454.8 megawatts of solar PV and not a single watt of wind had gone online through such equity investments" Greenpeace 2019). The press release quotes several Chinese Greenpeace campaigners concerning the balance of solar and coal-fired electrical investments: "'Solar now presents a serious rebuttal to any pattern of Chinese overseas pro-coal bias,' said Liu Junyan, a Beijing-based climate and energy campaigner with Greenpeace East Asia. 'Chinese investors' ratio of coal to solar is now the same at home and abroad - both are still six-to-one coal, unfortunately, but I'm amazed to see what five years of equity investment in solar made possible" (Meaning BRI energy investments were no more coal-fired than Chinese domestic electricity).

Probably the most negative NGO assessment of the BRI was published by the Sierra Club in December 2019. The article's tone is wholly negative: “...China's Belt and Road Initiative [is] a colonial-style endeavor that links infrastructure loans with geostrategic diplomacy" (Ives 2019). The article continues, “...many Chinese companies apply weaker environmental standards abroad than they do at home, and many conservation experts are skeptical about Beijing's assurances.” The potential damage is described in catastrophic terms: “...it threatens to 'open a Pandora's box of environmental crises, including large-scale deforestation, habitat fragmentation, wildlife poaching, water pollution, and greenhouse gas emissions."

The ability of international NGOs to work and monitor conditions within China has begun to be much more constrained as of 2017, when the "Law of the People's Republic of China on Administration of Activities of Overseas Nongovernmental Organizations in the 
Mainland of China" went into effect, requiring NGOs to apply for legal status. According to China Environment Yearbook 2018 (Eng. ver., 275) five such NGOs were granted legal status by the end of 2017: the Environmental Defense Fund, ClientEarth, Community Partners, the Rockefeller Brothers Fund, and the World Resources Institute.

It may be indicative of China's concerns about international NGO criticism of its flagship program, however, that it has also sought to create a forum for NGO participation in the BRI. The Belt and Road Initiative International Green Development Coalition (BRIGC) was established in April 2019 at the Second Belt and Road Forum. The body is supervised by the MEE but has its own secretariat headed by a German, and has a large number of organizations which have joined, including ClientEarth, the Environmental Defense Fund, the Global Green Growth Institute, the World Wildlife Fund, the World Resources Institute, and the International Institute of Sustainable Development. The UN Environment Program also belongs (Green Belt and Road Initiative Center 2020). Greenpeace Asia does not belong, and some Western environmental groups have questioned whether this organization is just a "Green Washing" effort by China.

Push-Back from BRI Partners. As the financial problems in Sri Lanka's Hambantota Port forced a renegotiation of the payment of that (pre-) BRI project, several partners countries became more wary of the "debt trap diplomacy" rhetoric coming out of Washington, and paused. A Kenyan court halted construction of a coal-fired power plant in 2018 over environmental concerns (Nakano 2019, 2). Pakistan also pushed back on some of the CPEC/BRI energy projects, such as the cancelation of the Rahim Yar Khan Power Plant, a 1,320MW facility slated to use imported coal for electrical generation in Punjab; the deal had been originally signed in June 2017 but was canceled in January 2019 (Kiani 2019). The justification was "in order to 
provide structure optimisation space for the subsequent power market of Pakistan.” No mention of environmental concerns was mentioned in this case.

Some of the push-back from Pakistan reflects domestic party politics as opposed to genuine environmental concern. The CPEC was launched in 2015 and quickly taken in as part of the BRI, indeed in some ways its flagship. But the government in Islamabad which negotiated the deals was that of Pakistan Muslim League's Nawaz Sharif, who was removed from office in July 2017 on corruption charges. In the subsequent 2018 general election, former cricket player Imran Khan became Prime Minister, and had campaigned on a platform seeking to renegotiate aspects of the CPEC deals. The Pakistani military then rolled back the pushback to assure China that its "All-Weather Ally" was still deeply committed to the overall project, if not to all particulars (Afzal 2020, 2-3).

Internal Push Factors. Civil society in any authoritarian state such as China is highly constrained. Nevertheless, there are environmental groups in China independent of the Communist Party. One of their most famous achievements was when Chinese microbloggers, using the air pollution data of the US Embassy in Beijing, publicized the air quality problem there (Kay 2015). Jennifer Turner and Kenji Otsuka note the role of river-based Chinese NGOs in focusing attention on water pollution in 2006 (Turner and Otsuka 2006, 14-16). Scores of Chinese environmental NGOs continue to monitor pollution issues in China, seeking to use the press as an outlet for reporting (Wang Yongchen and Wan Aijun 2012). The role of the Eco Forum's Global Annual Conference in 2016 is another example of a Chinese NGO presenting a timely forum for ideas that would quickly be adopted by top leaders in China. However, although the activities of Chinese environmental NGOs has been a substantial factor in the increased attention of the Chinese government to pollution issues beginning in the $21^{\text {st }}$ century, it 
is unclear how much Chinese domestic civil society influenced the "greening" of the Belt and Road Initiative.

Bureaucratic factors, on the other hand, do appear to have had an influence in "pushing" the Center for a green Belt and Road. The Ministry of Environmental Protection (MEP, renamed the Ministry of Ecology and Environment [MEE] in 2018) can be seen as the earliest "policy entrepreneur" of the OBOR. Then Vice-Minister Li Ganjie as noted above, was among the first to use the term "Green Belt and Road" in July 2015. After a brief stint as Deputy Party Secretary in Hebei (2016-17), he became Minister of the MEP, then MEE in 2018. The MEP signed a Memorandum of Understanding with the UN Environment Programme in December 2016 on "Building a 'Green Belt and Road"” (UNEP 2016). It had been given the task of writing The Belt and Road Ecological and Environmental Cooperation Plan to be issued during the first Belt and Road Forum, giving it a bureaucratic responsibility for a portion of Xi Jinping's pet project. The State Oceanic Agency also sought to push its some green into its "blue economy" program. External Pull Factors. Just as the world turned toward environmental protection in 2015 and China was "pushed" into a variety of policy changes, such as "greening" the Belt and Road Initiative, there were also opportunities that "pulled" China toward the same end. China's industry moved quickly into low-carbon energy fields such as solar, wind electrical generation, and as countries collectively announced at Paris that they would try to reduce their carbon emissions, China saw a chance to seize market share. China was second only to the United States in nuclear and renewable production in 2017 with $17.5 \mathrm{~b}$ BTUs which has more than doubled since 2010 (the USA produced 19.7b BTUs) (EIA 2020). China also had an advantage that its definition of "green" is broader than many Western countries; large hydroelectric dams have been largely shunned in the West since 2000, but China continues to build these as part of 
its "green" push, and is happy to build them in other countries. The same is true of nuclear power plants, which China has built in Pakistan and is exploring deals elsewhere. Several of the speeches and documents announcing the BRI discuss the opportunities involved: "We will...foster a cluster of high-quality green brands in railway, electric power and other key areas" (State Council 2017); Li Keqiang as early as 2014 said "We will also promote the development of green industries, new energy, and energy-conserving and environment friendly technologies and products to foster new growth areas" (Li Keqiang 2014).

The other obvious "pull" factor was the global leadership space created by the election of Donald Trump as President of the United States. As promised in his campaign, his first act in office was to begin the withdrawal of the USA from the Paris Climate Accord. Subsequent policies of his administration have rolled back a variety of environmental protections and policies. Chinese President Xi Jinping could, in comparative context, pose China as a "leader" in environmental affairs, and world public opinion had greater confidence in Xi with than Trump in 2017: 27.2\% had confidence in Trump versus 30\% for Xi (Pew Global Attitudes 2020). Europeans were among the most negative in their views of Trump (though hardly enamored of $\mathrm{Xi})$.

The report by Sam Geall of the Lowy Institute noted the degree to which Xi Jinping and China was boosted by Trump's withdrawal from the Paris Climate Accord. "The US retreat was an easy victory for China, with Trump opening 'the door for China to emerge both as the world's leader in green technology ... and in international efforts to slow global warming"' (Geall 2017, 3). Yet the report is also skeptical about the short-term ability of Xi to harness world opinion, "[...China] faces major tests: at home in strengthening its domestic energy transition away from 
coal; and abroad in proving its green credentials through its overseas investments" (Geall 2017,

$1)$.

\section{Conclusion}

The shift in Chinese public discussions of the environmental impact of infrastructure projects is not insincere; the government does care about the environmental aspects of the BRI and really cares about the image of its initiative as being "green." The question is whether it is effective in changing construction design and implementation on the ground by the myriad of actors involved in large, complex and often far-away engineering projects. Carey and Ladislaw summarize the problem well:

While the commitment to ending perceptions of "debt-trap diplomacy" and environmental negligence appear credible enough at the highest level, Chinese authorities continue to face difficulties in reigning in the multitude of actors working within its belt and Road framework. The Chinese have a famous proverb... which translates as "the mountains are high, and the emperor far away." In other words, central authorities are perceived to have little influence over local affairs (5).

Harsh criticism of the environmental impact of the BRI have been transformed to an extent to skepticism. But the sense of many western think tanks and analysts is summarized well by Carey and Ladislaw:

The extent to which China successfully manages to green the BRI will be based on its ability to either add teeth to its own foreign investment regime or facilitate improved environmental standards in host countries. While new multilateral institutions may help with the latter, these initiatives will only be successful if the[y] lead to concrete changes in China's actions...(Carey and Ladislaw 2019, 6).

In some ways, the effort to green the BRI have been rendered at least temporarily meaningless during the Covid-19 pandemic; with much of the world economy curtailed or shut down, and the specter of a global depression looming, world attention on the BRI has been 
reduced. Instead, the initiative has been melded onto a new idea, the "Health Silk Road," China's Covid-19 aid program. 


\section{Works Cited}

ADB [Asian Development Bank]. 2005. Connecting East Asia: A New Framework for Infrastructure. Manila. In cooperation with the International Bank for Reconstruction and Development/The World Bank, and Japan Bank for International Cooperation.

Afzal, Madiha. 2020. "At all costs": how Pakistan and China control the narrative on the ChinaPakistan economic corridor. Brookings Institution: Global China: Assessing China's Growing Role in the World. < https://www.brookings.edu/research/at-all-costs-howpakistan-and-china-control-the-narrative-on-the-china-pakistan-economic-corridor/>, accessed June 16, 2020.

AIIB [Asian Infrastructure Investment Bank]. 2020. Our projects. <https://www.aiib.org/en/projects/list/index.html?status=Approved $>$, accessed July 27, 2020.

Bhattacharyay, Biswa, Nath Masahiro Kawai, and Rajat M. Nag, editors. 2012. Infrastructure for Asian Connectivity. Cheltenham, UK: Edward Elgar.

Blinken, Antony J. 2015. An enduring vision for Central Asia. US Department of State. March 31. 〈https://2009-2017.state.gov/s/d/2015/240013.htm>, accessed June 10, 2020.

Bolton, John R. 2018. Remarks by National Security Advisor Ambassador John R. Bolton on the Trump Administration's new Africa strategy. White House. December 13. < https://www.whitehouse.gov/briefings-statements/remarks-national-security-advisorambassador-john-r-bolton-trump-administrations-new-africa-strategy/>, accessed June 10, 2020.

Buckley, Tim. 2019. IEEFA Report: every two weeks a bank, insurer announces new coal restrictions. February 26. Institute for Energy Economics and Financial Analysis. < https://ieefa.org/ieefa-report-every-two-weeks-a-bank-insurer-or-lender-announces-newcoal-restrictions/>, accessed June 10, 2020.

Cai, Peter. 2017. Understanding China's Belt and Road Initiative. Sydney: Lowy Institute for International Policy.

Carey, Lachlan, and Sarah Ladislaw. 2019. CSIS Briefs: Chinese multilateralism and the promise of a Green Belt and Road. November. Washington DC: Center for Strategic and International Studies.

China Environment Yearbook. 2018. Beijing: China Forum of Environment Journalists.

CRS [Congressional Research Service]. 2017. Asian Infrastructure Investment Bank (AIIB). Congressional Research Service. March 10, no. R44754.

Desai, Raj M. and James Raymond Vreeland. 2015. How to sop worrying and love the Asian Infrastructure Investment Bank. Washington Post. Blog: "Monkey Cage". $<$ https://www.washingtonpost.com/news/monkey-cage/wp/2015/04/06/how-to-stopworrying-and-love-the-asian-infrastructure-investment-bank/>, accessed April 8, 2015.

EIA [Energy Information Agency]. 2020. China Rankings: Total energy production from nuclear, renewables, and other 2017. Energy Information Agency database. 
$<$ https://www.eia.gov/international/rankings/country/CHN?pa=289\&u=0\&f=A\&v=none $\& y=01 \% 2 F 01 \% 2 F 2017>$, accessed August 30, 2020.

Friends of Earth. 2017. Investing in a Green Belt and Road? Assessing the Implementation of China's Green Credit Guidelines Abroad. December. Washington DC: Friends of the Earth United States.

Gan, Nectar, and Robert Delaney. 2019. United States under Donald Trump is veering away from China's belt and road. South China Morning Post. April25.

<https://www.scmp.com/news/china/article/3007504/united-states-under-trump-veeringaway-chinas-belt-and-road>, accessed May 20, 2020.

Geall, Sam. 2017. Clear waters and green mountains: will Xi Jinping take the lead on climate change? November. Sydney: Lowy Institute. $<$ https://www.lowyinstitute.org/publications/clear-waters-and-green-mountains-will-xijinping-take-lead-climate-change>, accessed June 13, 2020.

Gough, Neil. 2015. An upside-down economy. New York Times, March 12. <http://www.nytimes.com/2015/03/12/business/international/for-chinese-economy-steelgoes-from-strength-toweakness.html>, accessed June 20, 2020.

Green Belt and Road Initiative Center. 2020. Understanding the Belt and Road Initiative International Green Development Coalition (BRIGC), Christoph Nedopil Wang, April 2. <https://green-bri.org/understanding-the-belt-and-road-initiative-green-coalition-brigc >, accessed June 13, 2020.

Greenpeace. 2017a. Belt and Road participants call for full implementation of Paris Agreement. Greenpeace East Asia, May 15. <https:/wwww.greenpeace.org/eastasia/press/1032/beltand-road-participants-call-for-full-implementation-of-paris-agreement/>, accessed June $10,2020$.

Greenpeace. 2017b. Sustainability should be priority for China's Belt and Road- Greenpeace. Greenpeace East Asia. May 12. $<$ https://www.greenpeace.org/eastasia/press/1383/sustainability-should-be-priority-forchinas-belt-and-road-greenpeace/>, accessed June 10, 2020.

Greenpeace. 2019. Chinese equity investments in energy reshape South and Southeast Asia Greenpeace analysis. Greenpeace International. July 29.

<https://www.greenpeace.org/international/press-release/23446/chinese-equityinvestments-in-energy-reshape-south-and-southeast-asia-greenpeace-analysis/>, accessed June 10, 2020.

Ives, Mike. 2019. China's Belt and Road Initiative Threatens to Pave the Planet. Sierra: The National Magazine of the Sierra Club. December 16. <https://www.sierraclub.org/sierra/2020-1-january-february/feature/chinas-belt-and-roadinitiative-threatens-pave-planet>, accessed June 10, 2020.

Johnson, Christopher K. 2016. President Xi Jinping's “Belt and Road” Initiative. Washington DC: Center for Strategic and International Studies.

Joy-Perez, Cecilia, and Derek Scissors. 2017. A close look at OBOR reveals overstated gains. Washington DC: American Enterprise Institute. 
Kamal, Rohini, and Kevin P. Gallagher. 2016. At Issue: China goes global with development banks. Bretton Woods Project. April. <https://www.brettonwoodsproject.org/wpcontent/uploads/2016/04/At-Issue-China-goes-global-with-development-banks.pdf>, accessed September 1, 2020.

Kay, Samuel, Bo Zhao and Daniel Sui. 2015. Can social media clear the air? A case study of the air pollution problem in Chinese cities. The Professional Geographer, 67:3,351-363.

Kiani, Khaleeq. 2019. Govt puts major CPEC power project on hold. Dawn 14 Jan <https://www.dawn.com/news/1457449>, accessed Sept. 5, 2020.

Kuhn, Berthold M. 2018. Chna's commitment to the Sustainable Development Goals: an analysis of push and pull factors and implementation challenges. Chinese Political Science Review, 3: 359-388.

Li Keqiang. 2014. Jointly open up new vistas for Asia's development. Boao Forum. <http://english.boaoforum.org/ac2014news/13474.jhtml), accessed July 29, 2020.

Li Zhaoxing. 2015. Building the Maritime Silk Road of the $21^{\text {st }}$ Century with open mind and bold courage. Ministry of Foreign Affairs of the People's Republic of China. <https://www.fmprc.gov.cn/mfa_eng/wjdt_665385/zyjh_665391/t1237173.shtml>, accessed June 22, 2020.

MEE [Ministry of Ecology and the Environment]. 2015a. The $4^{\text {th }}$ meeting of China-Kazakhstan Environmental Cooperation Committee opens in Kazakhstan. MEE.

<http://english.mee.gov.cn/About_MEE/leaders_of_mee/liganjie_old/activities_9795/201 502/t20150228_296222.shtml>, accessed June 24, 2020.

MEE. 2015b. Activities: Li Ganjie Meets with Chief of Cabinet for Ministry of Environment, Cambodia and Signs MOU on Environmental Cooperation between China and Cambodia. Ministry of Ecology and Environment. July 1.

<http://english.mee.gov.cn/About_MEE/leaders_of_mee/liganjie_old/activities_9795/201 507/t20150701_304592.shtml>, accessed June 24, 2020.

MEE. 2015c. Build green silk road: green economic development and transition. Ministry of Ecology and Environment. September 25. <http://english.mee.gov.cn/About_MEE/leaders_of_mee/liganjie_old/activities_9795/201 510/t20151012_314831.shtml>, accessed June 24, 2020.

MEE. 2017. Vision for maritime cooperation under the Belt and Road Initiative. Ministry of Ecology and Environment. June 21.

<http://english.mee.gov.cn/News_service/media_news/ 201706/t20170621_416432.shtml>, accessed June 24, 2020.

Nakano, Jane. 2019 Greening or greenwashing the Belt and Road Initiative? Center for Strategic and International Studies. May 1. < https://www.csis.org/analysis/greening-orgreenwashing-belt-and-road-initiative>, June 10, 2020.

National Security Council. 2020. United States strategic approach to the People's Republic of China. White House. May 26. < https://www.whitehouse.gov/articles/united-statesstrategic-approach-to-the-peoples-republic-of-china/>, accessed June 10, 2020. 
NDRC [National Development and Reform Commission]. 2015. Vision and Actions on Jointly Building Silk Road Economic Belt and $21^{\text {st }}$ Century Maritime Silk Road, First Edition. National Development and Reform Commission/Internet Archive. <https://web.archive.org/web/20181127225143/http://en.ndrc.gov.cn/newsrelease/201503 /t20150330_669367.html>, accessed June 8, 2020.

Office of the Leading Group [for the Belt and Road Initiative]. 2017. Building the Belt and Road: Concept, Practice and China's Contribution. Beijing: Foreign Languages Press.

Perlez, Jane. 2014. US opposing China's answer to World Bank. New York Times, October 9. $<$ https://www.nytimes.com/2014/10/10/world/asia/chinas-plan-for-regionaldevelopment-bank-runs-into-us-opposition.html>, accessed October 9, 2014.

Perlez, Jane. 2015a. Hostility from US as China lures allies to new bank. New York Times, March 19. <https://www.nytimes.com/2015/03/20/world/asia/hostility-from-us-as-chinalures-allies-to-new-bank.html>, accessed March 20, 2015.

Perlez, Jane. 2015b. New China-led bank pledges to fend off graft. New York Times, April 11. <https://www.nytimes.com/2015/04/12/world/asia/new-china-led-bank-pledges-to-fendoff-graft.html>, accessed April 11, 2015.

Pew Global Attitudes Project. 2020. Global indicators database. $<$ https://www.pewresearch.org/global/database/indicator/69><https://www.pewresearch. org/global/database/indicator/6), accessed August 30, 2020.

Prestowitz, Clyde. 2016. The TPP Deal Won't Stop China. Op-Ed. The New York Times, August 23 <http://www.nytimes.com/2016/08/23/opinion/why-the-tpp-deal-wont-improve-oursecurity.html $>$, accessed June 20, 2020.

Qian Hongshan. 2016. Remarks by Assistant Foreign Minister Qian Hongshan At the Belt and Road Side Event Of the 72nd Session of the United Nations Economic and Social Commission for Asia and the Pacific. Ministry of Foreign Affairs of the People's Republic of China. May 16. <https://www.fmprc.gov.cn/mfa_eng/wjdt_665385/zyjh_665391/t1364753.shtml>, accessed 6/22/20.

Ratner, Ely. 2014. Making bank. Foreign Policy, Oct. 23. <https://foreignpolicy.com/2014/10/23/making-bank/>, accessed July 26, 2020.

Russel, Daniel R. Q\&A at 'Looking East- trend lines in the Asia Pacific.' US Department of State. March 22. < https://2009-2017.state.gov/p/eap/rls/rm/2016/03/255132.htm>, accessed June 10, 2020.

Schüller, Margot and Yun Schüler-Zhou. 2015. Chinas Seidenstraßen-Initiative trifft auf transeuropäische Infrastrukturpolitik [China's Silk Road meets trans-European infrastructure policy]. GIGA Focus, no. 8. (December). Hamburg: Institut für AsienStudien. < https://www.giga-hamburg.de/en/publication/chinas-seidenstrassen-initiativetrifft-auf-transeuropaeische-infrastrukturpolitik>, accessed June 13, 2020.

Silk Road Fund. 2019. "Silk Road Fund and ACWA Power jointly build the renewable energy platform. Silk Road Fund website, September 11. <http://www.silkroadfund.com.cn/enweb/23809/23812/40996/index.html>, accessed July $28,2020$. 
Silk Road Fund. 2020. Scope of investment. Silk Road Fund website. <http://www.silkroadfund.com.cn/enweb/23798/23805/index.html>, accessed July 27, 2020.

Sobolewski, Matthias and Jason Lange. 2015. US urges allies to think twice before joining China-led bank. Reuters, March 17. < https://www.reuters.com/article/us-europe-asiabank/u-s-urges-allies-to-think-twice-before-joining-china-led-bankidUSKBNOMD0B320150318>, accessed March 19, 2015.

State Council. 2017. Guidance on promoting green belt and road. Belt and Road Portal. <https://eng.yidaiyilu.gov.cn/zchj/qwfb/12479.htm>, accessed August 29, 2020.

Tiezzi, Shannon. 2014. China’s 'New Silk Road' Vision Revealed. The Diplomat. May 9. <https://thediplomat.com/2014/05/chinas-new-silk-road-vision-revealed/>, accessed September 4, 2020.

Tong, Kurt. 2016. The Potential of the Trans-Caspian Trade Route. US Department of State. April 28. <https://2009-2017.state.gov/e/eb/rls/rm/2016/256782.htm>, accessed June 10, 2020.

Turner, Jennifer, and Kenji Otsuka. 2006. Reaching Across the Water: International Cooperation Promoting Sustainable River Basin Governance in China. Washington DC: Wilson Center.

UNEP. 2016. Memorandum of understanding between the United Nations Environment Programme and the Ministry of Environmental Protection of the People's Republic of China on building a green "Belt and Road." United Nations Environment Programme, December 8. MOU/2016/United Nations Environment Programme/ Ministry of Environmental Protection China/Asia and Pacific Office/003.

Van der Putten, Frans-Paul, and Minke Meijnders. 2015. China, Europe, and the Maritime Silk Road. The Hague: Clingendael/Netherlands Institute of International Relations. <https://www.clingendael.org/sites/default/files/pdfs/China_Maritime_Silk_Road.pdf>, accessed September 1, 2020.

Wang Yongchen and Wang Aijun. 2012. Shouwang: Zhongguo huanbao NGO meiti diaocha.[Watching: media investigation into Chinese environmental NGOs. Beijing: Chinese Environmental Services Publishers.

World Commission on Dams. 2000. Dams and Development: A New Framework for DecisionMaking. Report of the World Commission on Dams. London: Earthscan Publications.

Wright, Thomas. 2015. A special argument: the US, UK, and the AIIB. Brookings blog: "Order from chaos," March 13. <https://www.brookings.edu/blog/order-fromchaos/2015/03/13/a-special-argument-the-u-s-u-k-and-the-aiib/>, accessed March 15, 2015.

Xi Jinping. 2013a. Promote friendship between our people and work together to build a bright future. Speech at Nazarbayev University. Ministry of Foreign Affairs of the People's Republic of China. <https://www.fmprc.gov.cn/mfa_eng/wjdt_665385/zyjh_665391/t1078088.shtml>, accessed June 7, 2020. 
Xi Jinping. 2013b. Speech by Chinese President Xi Jinping to Indonesian parliament. Ministry of Foreign Affairs of the People's Republic of China. <http://www.asean-chinacenter.org/english/2013-10/03/c_133062675.htm>, accessed July 26, 2020.

Xi Jinping. 2013c. President Xi Jinping delivers important speech and proposes to build a silk road economic belt with Central Asian countries. Ministry of Foreign Affairs of the People's Republic of China. <https://www.fmprc.gov.cn/mfa_eng/topics_665678/xjpfwzysiesgjtfhshzzfh_665686/t10 76334.shtml>, accessed June 7, 2020.

Xi Jinping. 2013d. Deepen Reform and Opening up and Work Together for a Better Asia Pacific: Address by H.E. Xi Jinping President of the People's Republic of China to the APEC CEO Summit. Oct. 9. Ministry of Foreign Affairs of the People's Republic of China. <https://www.fmprc.gov.cn/mfa_eng/wjdt_665385/zyjh_665391/t1088517.shtml>, accessed June 9, 2020.

Xi Jinping. 2015. Towards a Community of Common Destiny and a new future for Asia. Boao Forum/Xinhua. March 28. < http://www.xinhuanet.com//english/201503/29/c_134106145.htm>, accessed July 29, 2020.

Xi Jinping. 2017. Work together to build the Silk Road Economic Belt and the $21^{\text {st }}$ Century Maritime Silk Road. Ministry of Foreign Affairs of the People's Republic of China. May 15. < https://www.fmprc.gov.cn/mfa_eng/wjdt_665385/zyjh_665391/t1465819.shtml>, accessed June 7, 2020.

Xi Jinping. 2019. Promoting high-quality development of Belt and Road cooperation. Ministry of Foreign Affairs of the People's Republic of China. April 27. <https://www.fmprc.gov.cn/mfa_eng/wjdt_665385/zyjh_665391/t1659454.shtml>, accessed June 22, 2020.

Xi Jinping. 2020. Remarks by H.E. Xi Jinping President of the People's Republic of China at the opening ceremony of the fifth annual meeting of the Asian Infrastructure Investment Bank. Ministry of Foreign Affairs of the People's Republic of China. <https://www.fmprc.gov.cn/mfa_eng/zxxx_662805/t1801603.shtml>, accessed July 29, 2020 .

Xinhua. 2016a. President Xi calls for building 'green, healthy, intelligent and peaceful' Silk Road. Xinhua/Ministry of Ecology and Environment. June 27. <http://www.scio.gov.cn/32618/Document/1481477/1481477.htm>, accessed July 31, 2020.

Xinhua. 2016b. Xinhua insight: Belt and Road Initiative needs to be green. Xinhua/Ministry of Ecology and Environment. July 12. <http://english.mee.gov.cn/News_service/media_news/201607/t20160712_360517.shtml $>$, accessed June 24, 2020.

Xue Guifang. 2005. China and International Fisheries Law and Policy. Leiden: Martinus Nijhoff.

Yang Jiechi. 2014. Jointly undertake the great initiatives with confidence and mutual trust. Boao Forum. <http://english.boaoforum.org/ac2014news/13794.jhtml>, accessed July 29, 2020. 
Yang Jiechi. 2015. Jointly Build the 21st Century Maritime Silk Road By Deepening Mutual Trust and Enhancing Connectivity. Boao Forum. March 29.

<https://www.fmprc.gov.cn/mfa_eng/zxxx_662805/t1249761.shtml>, accessed July 29, 2020.

Zhou, L., S. Gilbert, Y. Wang, M. Muñoz Cabré, and K. P. Gallagher. 2018. Moving the Green Belt and Road Initiative: from words to actions. Working Paper. World Resources Institute. October. Washington DC: World Resources Institute.

<http://www.wri.org/publication/moving-the-green-belt>, accessed June 10, 2020.

Zhu Shouqing. 2017. 4 ways China's Belt and Road Initiative could support sustainable infrastructure. World Resources Institute blog. May 22.

$<$ https://www.wri.org/blog/2017/05/4-ways-china-s-belt-and-road-initiative-couldsupport-sustainable-infrastructure >, accessed June 10, 2020. 